\title{
原著
}

\section{テトラサイクリン投与ラットの 龂蝕罹患性に関する研究*}

\author{
Study on the Caries Incidence of \\ Tetracycline Administered Rats
}

\author{
植 野 正之** \\ Masayuki UENO **
}

Received October 14, 1989 ; accepted November 15, 1989

\begin{abstract}
This study was designed to examine the caries incidence of tetracycline administered rats. The experiment was divided into three series. In the first series, the rats were daily injected subcutaneously with tetracycline hydrochloride $(50 \mathrm{mg} / \mathrm{kg}$ body weight) from 10 days of age to weaning at 21 days of age. Rats injected with saline solution served as controls, and caries incidence was compared. In the second series, the caries inhibitory effects of fluorides ( $\mathrm{NaF}$ in drinking water or topical application of APF) on tetracycline administered rats were assessed. In the third series, the acid resistance and the Vickers microhardness of enamel were measured in lower first molars.
\end{abstract}

The results obtained were as follows:

1) Compared with the control group, dental caries was significantly increased in tetracycline administered rats.

2) Dental caries in tetracycline administered rats was drastically reduced when fluorides were applied.

3) The acid resistance in tetracycline-affected enamel was decreased, but it was increased when fluorides were applied.

Microhardness of tetracycline-affected enamel was decreased, but a rehardening was shown when APF was topically applied.

On the basis of these results, I conclude that the caries resistance is decreased in tetracycline administered rats by reduction in acid resistance and hardness of tetracycline-induced hypoplastic enamel, but it is increased when fluorides are applied.

索引用語 : テトラサイクリン, 実験能触, 能触羅患性, フッ素

Koy words: Tetracycline, Experimental dental caries, Caries incidence, Fluoride

\footnotetext{
*本論文の要旨は，第38回日本口腔衛生学会において発表した。

** 東京医科歯科大学齿学部予防歯科学教室（主任：岡田昭五郎教授）

** Department of Preventive Dentistry and Public Health, Tokyo Medical and Dental University, Faculty of Dentistry (Director: Prof. Shogoro OKADA)
} 


\section{舶 言}

エナメル質の形成不全を伴う踩については，蝕感受 性が高いとする䂱とそうでないとする説があり，両者の 間に古くから論争が行なわれてきた。Mellanby1) は形

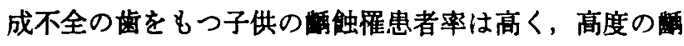
蝕に進行する割合も高いと報告している。これに対し て, Staz ${ }^{2,3)}$ は形成不全の歯は正常に形成された歯に比 べ㙑触感受性が低いと報告している。

歯の形成時期に過剩のフッ素を拯取した場合に起こる 齔牙フッ素症ではエナメル澌の形成不全や石灰化不全を 伴うが, 触の発生は極めて 少ないことが知られてい る4,5)。また，齿の形成時期にビタミンDが不足するとエ ナメル倎に形成不全を生じることがあるが, Wilsonら ${ }^{6)}$ はクル病の子供の歯を調べ, 形成不全の程度が強いほど 触䍜患者率は高くなると埌告している。しかし, Shel ling ら7はクル病による形成不全齿と偊蝳感受性との 間には何ら関倸はみられないと埌告している。

近年，わが国では重症の歯牙フッ素症やビタミン Dの 不足によるエナメル犋形成不全の歯を見る機会は少なく なったが、全身的な疾患や局所的な要因によるエナメル 兵形成不全の歯やテトラサイクリン系薬物の影響による と思われる着色歯を見かけることは少なくない。

幼児期にテトラサイクリン系薬物を長期間投与される と永久齔に歯の着色が見られることはよく知られている が，このような画がエナメル質の形成不全，石灰化不全 を伴っている場合があることや，テトラサイクリン系楽 物を投与した動物の歯に薬物による着色や石灰化不全が 認められることが報告されている8-11)。一方，テトラサ イクリン系薬物によると思われる着色歯の皬触䍜患性に

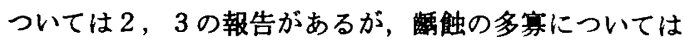
意見の一致を見ていない。

本研究は踩の形成, 石灰化時期にテトラサイクリン系 薬剤の投与を受けた歯の䙵強䍜患性について検討する目 的で，ラットを用いた動物実験を行ない，興味ある知見 を得たので報告する。

\section{実験材料および方法}

\section{1. 実験動物および飼育方法}

動物は日本クレア社より Wistar 系ラットを購入し， 本学付属動物実験施設（温度 $23 \pm 2{ }^{\circ} \mathrm{C}$, 湿度 $60 \%, 6 \sim$ 21時点燈，21〜 6時消燈）で繁殖させ，実験にはその仔 ラットを使用した。親ラットの飼育には通常は日本クレ ア CE-2 飼料を用い, 殖時にはオリエンタル MNF飼
料を用いた。授乳期間中は母ラット 1 匹当り仔ラット 8 〜10匹として飼育した。実験に使用した仔ラットは21日 龄で離乳し，可及的に同腹のラットおよび雌雄が各群に 均等になるように配分した。

本研究においては, 実験 1 , 実験 2 , 実験 3 の各々に 分けて動物を飼育した。いずれの実験においても離乳後 は，動物を自動給水装置付きのステンレススチール製ケ ージに 4〜 5 匹ずつ入れ, 動物が新触誘発性食慨 (Diet \#2000，船橋農場製）と飲料水を自由に鼬取できるよう にして飼育を行なった。飲料水は実験 2 , 実験 3 におけ るフッ化物溶液飲用群以外は自動給水装置による水道水 給水とした。実験期間中は週 1 回, 動物の体重測定を行 なった。

離乳後は，離乳した日を第 1 日目と数えて，実験 1 で は30日目すなわち50日龄, 40日目 (60日龄)，50日目 $(70$ 日龄)，60日目 (80日龄) まで，実験 2 では50日目（70 日龄）まで，実験 3 では10日目（30日龄）まで飼育した。

2. 塩酸テトラサイクリンの投与方法

実験 1 の第 1 群, 実験 2 のすぺての群, 実験 3 の第 1 群，第 3 群，第 4 群には，粉末塩酸テトラサイクリン （日本レダリー社製）を生理食塩水で $10 \mathrm{mg} / \mathrm{ml}$ 溶液に調 製し，体重 $10 \mathrm{~g}$ 当り $0.5 \mathrm{mg}$ 相当量を10日龄から21日龄 まで 1 日 1 回合計12回, 毎日17〜18時に背部に皮下注射 した。

実験 1 の第 2 群, 実験 3 の第 2 群には対照として生理 食塩水を体重 $10 \mathrm{~g}$ 当り $0.05 \mathrm{~m} l$ ずつ 10 日战から 21 日龄ま で毎日皮下注射した。

\section{3. フッ化物投与方法}

フッ化物溶液飲用群（実験 2 の第 2 群，実験 3 の第 3 群）の動物については水道水による給水を止め, フッ化 ナトリウム（以下 $\mathrm{NaF}$ と記す）で20ppm のフッ素を 含む水溶液を調整し, 合成樹脂容器の給水瓶に入れて与 え，亜物が自由に掑取できるようにして飼育した。

酸性フッ素リン酸溶液（以下 APF 溶液上記す）を塗 布する群の動物（実験 2 の第 3 群, 実験 3 の第 4 群）に は, 酸性フッ素リン酸溶液 ( $\mathrm{NaF}$ でフッ素 $0.9 \%, 0.15$ $\mathrm{M}$ リン酸を含む $\mathrm{pH} 3.6$ の溶液）を用意し，22日龄， 23 日龄，24日齢の連続 3 日間，上下額第 1 ，第 2 臼歯に 1 日 1 回染布を行なった。APF 溶液は歯科用ピンセット を用いてラットを開口させ，小綿球にて上下頡第 1 ，第 2 臼歯にそれぞれ約 1 分間ずっ局所塗布した。

\section{4. 踽䖪の評価方法}

動物は各実験の予定飼育期間終了後クロロホルム麻酔 下で殺し, 上下䫟を剔出し, 食片等の污物を除去した後 
10\%中性ホルマリンで 1 週間固定した。その後標本を水 洗し，実体顕微鏡下で JIS 規格10号のメリケン針を用 い掅窝の検索を行なった。

酙窝の検索を行なった後，実験 1 において50日跉，60 日龄まで飼育した動物および実験 2 の各群の動物につい

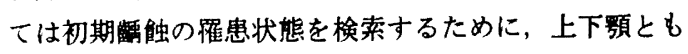
片側を $0.5 \%$ 㙁基性フクシン溶液で 4 時間染色, 水洗, 乾 燥後, Bronwill の Thin Sectioning Machine を用い, 厚さ約 $100 !$ m の薄切切片12)を 1 匹につき $4 \sim 5$ 枚作製 した。各切片は実体䫓微鏡下, 落下光線で観察し, エナ

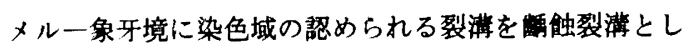
て禹触の評価13を行なった。

鳋の評価は第 1 日歯と第 2 臼歯について行なった。 第 3 日歯は歯牙の石灰化時期が遅いため評価からは除外

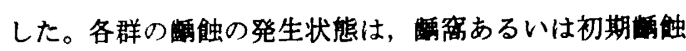

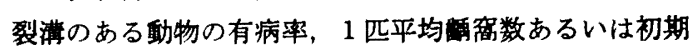

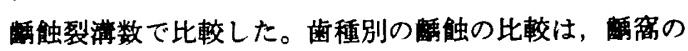
ある動物の有病率で行なった。

実験結果の平均值の差の有意性の検定は $\mathrm{t}$-検定で，母 分散の異なる 2 群の比較は Welch の方法により検定を 行なった。百分率の差の有意性の検定は $\gamma^{2}$ 検定および Fisher の直接確率計算法で行なった ${ }^{14}$ 。

5. エナメル質耐酸性の測定方法

実験 3 で飼育した動物について，下頶より第 1 日歯を 抜去し，食片等の污物を除去，流水中で水洗後，歯肉縁 下に相当する部分をスティッキーワックスで被覆し， $\mathrm{pH} 4.6,0.1 \mathrm{M}$ 酢酸一酢酸ナトリウム緩衙萑 $1 \mathrm{~m} l$ 中に $37^{\circ} \mathrm{C}$ で 6 時間浸瀆してェナメル質を脱灰させた。この
操作は 3 回連繶して行なった。

脱灰終了後, 脱灰溶液中に溶出したカルシウム量（以

下 Ca 量と記す) を，自動サンプリング装睓（Perkin Elmer AS-1) と原子吸光分光光度計 (Perkin Elmer AAS-603号) によって小椋ら ${ }^{15-17)} の$ 方法に従い測定し た。

耐酸性は脱灰溶液 $1 \mathrm{~m} l$ 中に溶出した Ca $(\mu \mathrm{g} / \mathrm{m} l)$ として比較した。

\section{6. エナメル兴微小硕度の測定方法}

実鈳 3 で飼育した動物について，下頻片側中央部を近 遠心方向に Bronwill の Thin Sectioning Machine を 用いて切断し，厚さ約 $500 u \mathrm{~m}$ の切片を作製した。切片 は測定面をエメリーペーパー（\#280～3000）で研磨し， 室温で24時間乾燥後, 微小硬度の測定を行なった。硬度

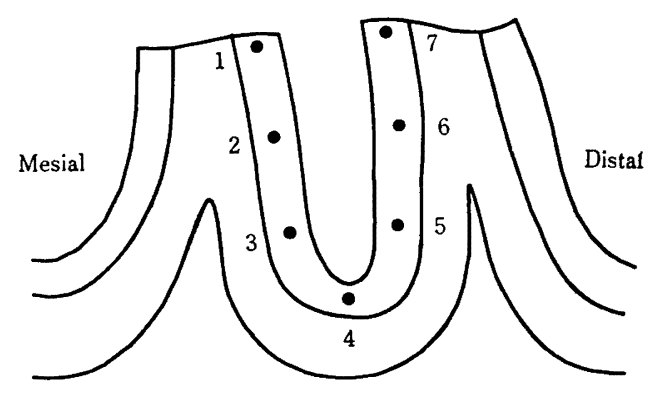

Note. This diagram shows the second fissure of lower first molar on ground section. Measured points are indicated 1-7.

Fig. 1 Measured points of microhardness.

\section{(Days after birth)}

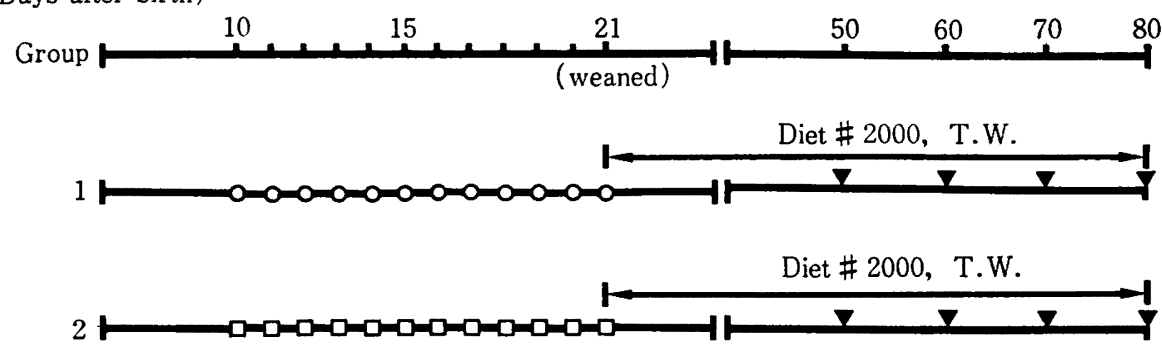

Note, T.W. : Tap water

$\mathrm{O}:$ Injection of tetracycline hydrochloride

: Injection of saline solution

$\nabla$ : Sacrifice

Fig. 2 Experimental schedule (experimental 1). 
Table 1 Growth of rats between start of experiment and weaning

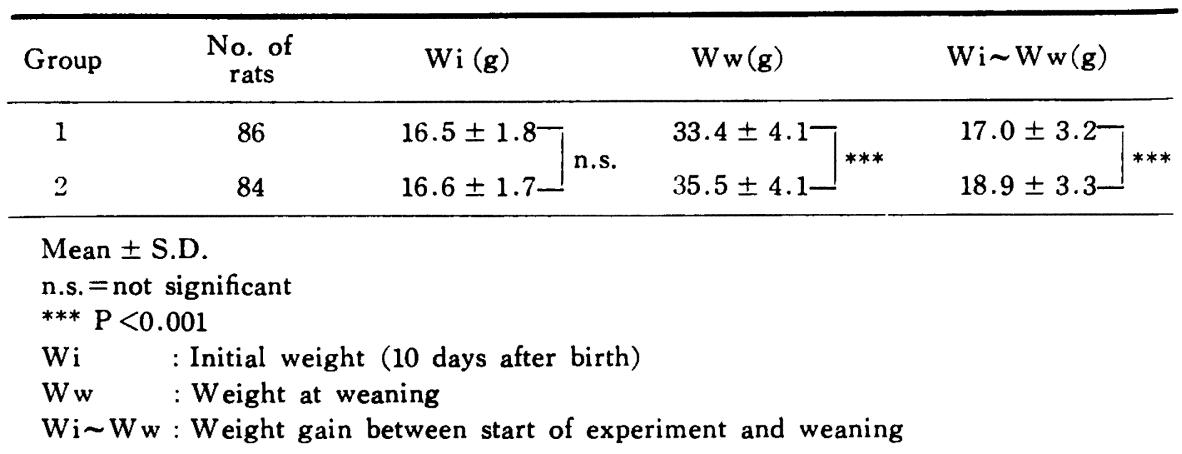

の測定は微小硬度計（MVK-C, 明石製作所）を用い， 荷重 $50 \mathrm{~g}$, 荷重時間 30 秒の条件でマイクロビッカース硬

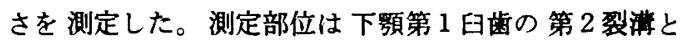
L，Fig. 1に示寸エナメル倎中の 7 点を選び，それぞれ エナメル倎の表層からエナメル象牙境までのほぼ中央部 で測定した。

\section{実験結果}

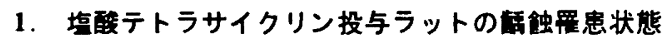
(実駼 1)

曰齒の形成，石灰化時期に塩酸テトラサイクリンを投 与したラットの触䍜患性を調へる目的で, Fig. 2 に 示す実験計画に従って対照群（生理食塩水投与群）との 比較を行なった。触誘発性飼料による飼育は50日龄, 60日龄，70日齢，80日齢までとした。

1）動物の発育状態

Table 1 に示すように，10日龄の体重は第 1 群（塩酸 テトラサイクリン投与群) と第 2 群(生理食塩水投与群) との間に $5 \%$ 以下の危険率で有意な差はみられなかった が, 離乳時の体重および10日龄から離乳時までの体重增 加量はいずれも第 2 群の方が第 1 群に比べ成長が速く, 第 1 群と第 2 群との間にはそれぞれ $0.1 \%$ の危険率で有 意な差がみられた。しかし，Table 2 に示すように実験 終了時の体重, あるいは離乳時から実験終了時までの体 重増加量は, 各群とも $5 \%$ 以下の危険率で有意な差はみ られなかった。

\section{2）醹の䍜患状態}

Fig. 3 に示すように, 䙵窝をもつ動物の有病率は第 1 群，第 2 群とも飼育期間が長くなるに従い高くなる。 50日龄，60日跉まで飼育した動物では第 1 群が第 2 群に 比べそれぞれ $5 \% ， 1 \%$ の危険率で有意に高い有病率 を示したが，70日齢，80日龄まで飼育した場合は第 1 群 の方が高い率を示す傾向にはあるが，5\%以下の危険率
で有意な差はみられなかった。

1 匹平均唡窝数は Fig. 4 に示すように両群とも飼育 期間が長くなるに従い増加する。第 1 群は第 2 群に比べ いずれの飼育期間の場合も 1 匹平均䙵窝数が多く，50日 龄まで飼育した場合は $5 \%$ の危険率で，60日龄，70日 龄，80日龄まで飼育した場合は $0.1 \%$ の危険率でそれぞ れ有意な差がみられた。

50日龄，60日龄まで飼育した動物において，初期属 蝕裂清をもつ動物の有病率と 1 匹平均初期解触裂清数を Table 3 に示す。初期触触裂窝をもつ動物の有病率は第 1 群と第 2 群の間に差異は認められなかった。1 匹平均 初期禹蝕裂渾数は50日龄，60日龄まで飼育した動物では いずれも第 1 群の方が高い数值を 示す傾向がみられる が，第 1 群と第 2 群との間に $5 \%$ 以下の危険事で有意な 差はみられなかった。

歯種別, 飼育期間別に䇎窝をもつ動物の有病率を Fig. 5 に示した。どの歯種においても第 1 群は第 2 群に比べ 解窝をもつ動物の有病率は高い傾向がみられるが，下頻 第 1 日歯では70日龄まで飼育した群，下額第 2 曰歯では 60日龄まで飼育した群，上顥第 2 臼歯では80日龄まで飼 育した 群のみに 5 \%以下の危険率で有意な 差がみられ た。

\section{2. フッ化物投与の影暨（实験 2)}

離乳前に塩酸テトラサイクリンを投与したラットにつ いて，離乳後フッ化物を応用した場合の触抑制効果を 検討するために, ラットを Fig. 6 に示す実験計画に従 い, 次の 3 群に分けて飼育し, 飽蝕の発生状態を比較し た。いずれの群の動物も，10日龄より21日龄まで毎日塩 酸テトラサイクリンの皮下注射を行ない，21日龄で 3 群 に分け, 第 1 群は対照群とし, 第 2 群は $\mathrm{NaF}$ 溶液飲用 群, 第 3 群は APF 溶液局所塗布群とした。触誘発性 飼料での飼育期間は離乳時より50日目（70日龄）までと した。 
Table 2 Growth of rats between weaning and end of experiment

\begin{tabular}{|c|c|c|c|c|c|}
\hline $\begin{array}{l}\text { Days after } \\
\text { birth }\end{array}$ & Group & Sex & $\begin{array}{l}\text { No. of } \\
\text { rats }\end{array}$ & $W f(g)$ & $\mathrm{W} \mathbf{w} \sim \mathrm{Wf}(\mathrm{g})$ \\
\hline \multirow{4}{*}{50 days } & \multirow{2}{*}{1} & $\sigma^{7}$ & 9 & $156.4 \pm 12.4$ & $120.6 \pm 10.9$ \\
\hline & & 우 & 12 & $138.4 \pm 11.1$ & $102.5 \pm 7.6$ \\
\hline & \multirow{2}{*}{2} & $0^{x}$ & 11 & $164.5 \pm 12.6$ & $126.5 \pm 10.4$ \\
\hline & & 우 & 9 & $140.1 \pm 10.1$ & $103.2 \pm 7.1$ \\
\hline \multirow{4}{*}{60 days } & \multirow{2}{*}{1} & $\sigma^{x}$ & 9 & $197.3 \pm 16.7$ & $162.7 \pm 14.3$ \\
\hline & & 우 & 12 & $154.7 \pm 10.9$ & $119.9 \pm 9.5$ \\
\hline & \multirow{2}{*}{2} & $\sigma^{7}$ & 12 & $201.3 \pm 10.9$ & $164.3 \pm 9.6$ \\
\hline & & 우 & 8 & $156.5 \pm 6.6$ & $120.5 \pm 6.6$ \\
\hline \multirow{4}{*}{70 days } & \multirow{2}{*}{1} & $\sigma^{7}$ & 12 & $235.1 \pm 14.3$ & $201.3 \pm 10.6$ \\
\hline & & 우 & 10 & $173.7 \pm 9.4$ & $143.4 \pm 9.9$ \\
\hline & \multirow{2}{*}{2} & $\sigma^{7}$ & 14 & $235.3 \pm 16.6$ & $200.8 \pm 12.7$ \\
\hline & & 우 & 8 & $172.1 \pm 8.8$ & $139.1 \pm 9.6$ \\
\hline \multirow{4}{*}{80 days } & \multirow{2}{*}{1} & $\sigma^{7}$ & 13 & $252.7 \pm 9.5$ & $211.5 \pm 9.1$ \\
\hline & & 우 & 9 & $182.7 \pm 9.0$ & $151.4 \pm 8.7$ \\
\hline & \multirow{2}{*}{2} & $\sigma^{x}$ & 14 & $257.4 \pm 13.1$ & $223.5 \pm 11.1$ \\
\hline & & 우 & 8 & $189.0 \pm 12.6$ & $154.8 \pm 11.1$ \\
\hline
\end{tabular}

Mean \pm S.D.

Wf : Final weight

$\mathrm{Ww} \sim \mathrm{Wt}$ : Weight gain between weaning and end of experiment

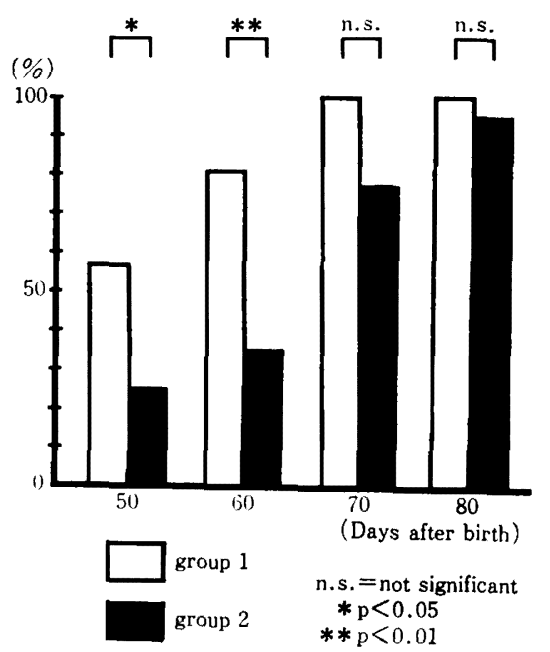

Fig. 3 Percentage of rats with carious cavities.

\section{1）動物の発青状態}

Table 4，5 に示すように，離乳時および実験終了時 の体重, 饲育期間中の体重增加量は各実験群の間に $5 \%$

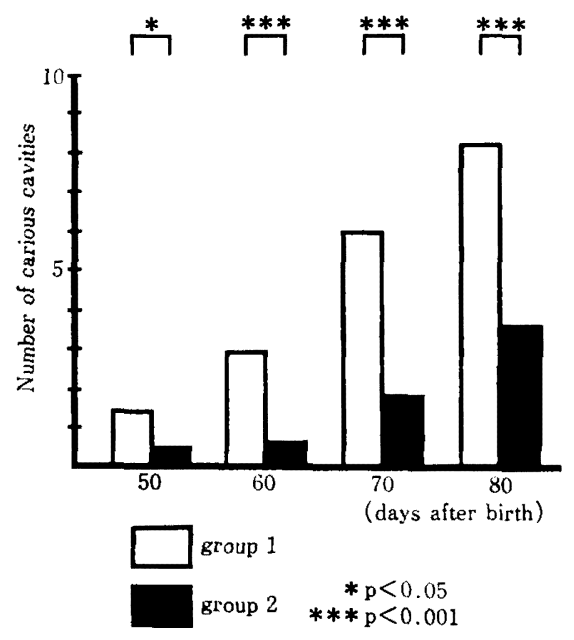

Fig. 4 Number of carious cavities per rat.

以下の危険率で有意な差はみられなかった。

2）觖蝕の两患状態

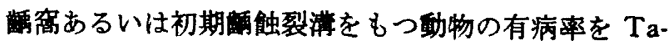
ble 6 に示す。埇䆚をもつ動物の有病來は第 1 群に比べ 

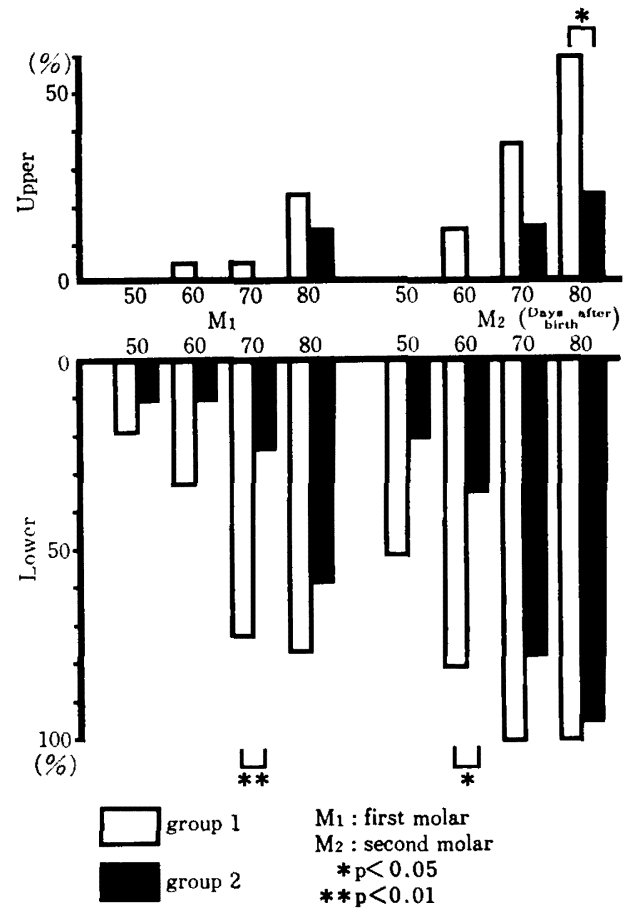

Fig. 5 Percentage of rats with carious cavities on specific molars.

て第 2 群, 第 3 群は幾分低い数值を示すが， $5 \%$ 以下の 危険率で有意な差は認められなかった。初期部蝕裂溝を もつ動物の有病率は各群の間に差異が認められなかっ
た。

1 匹平均龊窝数および初期龄触裂清数を Table 7 に 示した。離乳後フッ化物を投与した第 2 群, 第 3 群は第 1 群に比へ 1 匹平均槅禽数が少なく, 第 2 群, 第 3 群は いずれも第 1 群に比べ $0.1 \%$ の危険率で有意な差がみら れた。第 2 群と第 3 群との間には $5 \%$ 以下の危険率で有 意な差はみられなかった。

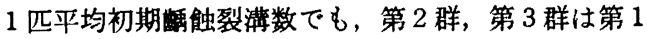
群に比べて小さい数值を示し，それぞれ $0.1 \%$ 危険率 で有意な差がみられた。また，第 2 群は第 3 群に比べ 5 \%の危険率で有意に初期穤触裂清数が少なかった。

Fig. 7 に示すように，歯種別に裸をもつ動物の有病 率を比較すると、ど歯種でも第 1 群に比べ第 2 群, 第 3 群の有病率は低く，上顥第 2 曰歯，下影第 1 臼歯では 第 2 群，第 3 群と第 1 群の閒に，それぞれ $5 \%, 0.1 \%$ の 危険率で有意な差がみられた。また，どの歯種において も第 2 群と第 3 群との間に有意な差はみられなかった。 第 2 群, 第 3 群で上額第 1 日歯に㵢窝のある動物は 1 匹 も認められなかった。

3.エナメル留の耐酸性ならびに微小硬度（実験 3)

10日龄から21日龄まで塩酸テトラサイクリンを投与し た動物，また，その後にフッ化物を投与した動物のエナ メル質の耐酸性の検索と, 微小硬度を测定する試料を得 るために, Fig. 8 に示寸実験計画に従い, 次の 4 群に分 け，各群10匹ずつ皤蝕誘発性飼料を与えて 30 日龄まで飼 育した。

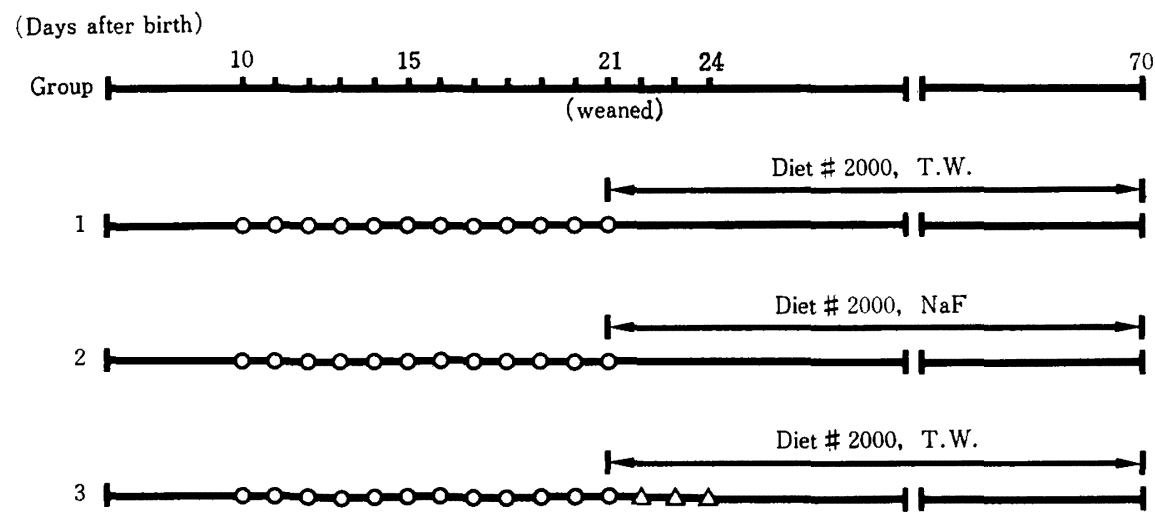

Note, T.W. : Tap water $\mathrm{NaF}: \mathrm{NaF}$ solution

$\mathrm{O}:$ Injection of tetracycline hydrochloride

$\triangle$ : Topical application of APF solution

Fig. 6 Experimental schedule (experimental 2). 
Table 3 Percentage of rats with carious fissures and number of carious fissures per rat

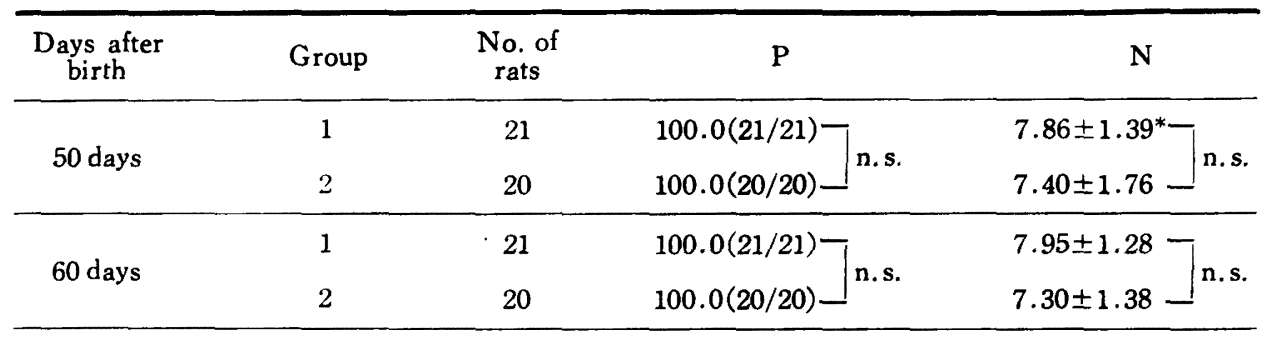

n.s. = not significant

* Mean \pm S.D.

$P$ : Percentage of rats with carious fissures

$\mathrm{N}$ : Number of carious fissures per rat on one side of jaw

Table 4 Growth of rats between start of experiment and weaning

\begin{tabular}{ccccc}
\hline Group & $\begin{array}{c}\text { No. of } \\
\text { rats }\end{array}$ & Wi $(g)$ & Ww $(g)$ & Wi $\sim$ Ww $(g)$ \\
\hline 1 & 21 & $16.3 \pm 1.8$ & $34.8 \pm 3.0$ & $18.4 \pm 2.0$ \\
2 & 22 & $16.1 \pm 2.2$ & $34.8 \pm 2.4$ & $18.7 \pm 1.7$ \\
3 & 22 & $16.2 \pm 1.9$ & $35.0 \pm 3.0$ & $18.8 \pm 1.9$ \\
\hline
\end{tabular}

Mean \pm S.D.

Wi : Initial weight (10 days after birth)

Ww : Weight at weaning

$\mathrm{Wi} \sim \mathrm{Ww}$ : Weight gain between start of experiment and weaning

Table 5 Growth of rats between weaning and end of experiment

\begin{tabular}{|c|c|c|c|c|}
\hline Group & Sex & $\begin{array}{l}\text { No. of } \\
\text { rats }\end{array}$ & $W f(g)$ & $\mathrm{W} w \sim \mathrm{Wf}(\mathrm{g})$ \\
\hline \multirow{2}{*}{1} & $\sigma^{\top}$ & 10 & $230.8 \pm 20.1$ & $195.7 \pm 19.6$ \\
\hline & 우 & 11 & $172.0 \pm 12.3$ & $137.5 \pm 9.3$ \\
\hline \multirow{2}{*}{2} & $\sigma^{\top}$ & 11 & $227.7 \pm 17.8$ & $192.3 \pm 15.9$ \\
\hline & 우 & 11 & $172.5 \pm 7.9$ & $139.3 \pm 8.3$ \\
\hline \multirow{2}{*}{3} & $0^{x}$ & 11 & $226.7 \pm 13.9$ & $190.6 \pm 13.4$ \\
\hline & 우 & 11 & $177.0 \pm 8.5$ & $142.2 \pm 7.1$ \\
\hline
\end{tabular}

Mean \pm S.D.

Wf : Final weight

$\mathrm{Ww} \sim \mathrm{Wf}$ : Weight gain between weaning and end of experiment

Table 6 Percentage of rats with carious cavities or fissures

\begin{tabular}{cccc}
\hline Group & $\begin{array}{c}\text { No. of } \\
\text { rats }\end{array}$ & Carious cavities & Carious fissures \\
\hline 1 & 21 & $100.0(21 / 21)-$ n.s. & $100.0(21 / 21)-$ \\
2 & 22 & $90.9(20 / 22)=$ n.s. & $100.0(22 / 22)=\mid$ n.s. \\
3 & 22 & $86.4(19 / 22)-$ n.s. & $100.0(22 / 22)-$
\end{tabular}

n.s. = not significant 
Table 7 Number of carious cavities or fissures per rat

\begin{tabular}{|c|c|c|c|c|c|c|c|}
\hline Group & $\begin{array}{l}\text { No. of } \\
\text { rats }\end{array}$ & Carious & cavities & & Carious fis & ssures & \\
\hline 1 & 21 & $6.71 \pm 3.57$ & \multirow{3}{*}{$\begin{array}{l}* * * \\
n . s .\end{array}$} & \multirow{3}{*}{$* * *$} & $8.76 \pm 0.62$ & & \multirow{3}{*}{$* * *$} \\
\hline 2 & 22 & $2.77 \pm 1.82=$ & & & $6.77 \pm 1.63=$ & & \\
\hline 3 & 22 & $2.32 \pm 1.76$ & & & $7.68 \pm 1.13$ & & \\
\hline
\end{tabular}

(Carious fissures were counted on one side of jaw)

Mean \pm S.D.

n.s. $=$ not significant

$* \mathrm{P}<0.05$

*** $\mathrm{P}<0.001$

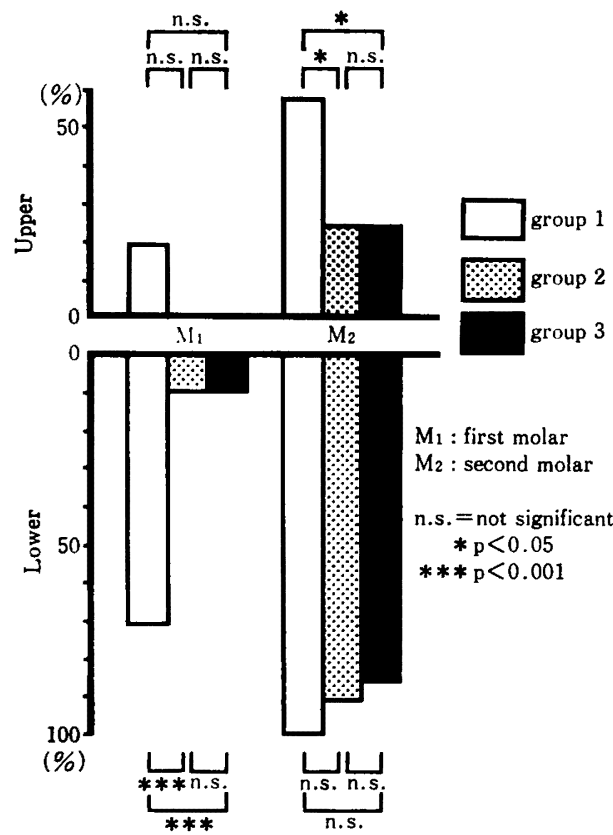

Fig. 7 Percentage of rats with carious cavities on specific molars.

第 1 群は10日龄から21日龄まで毎日 1 回塩酸テトラサ イクリンの皮下注射を行ない, 離乳後水道水を与えて飼 育した群とした。第 2 群はその対照群とし，10日领から 21日龄まで生理食塩水を皮下注射した群とし，離乳後は 水道水を与えて飼育した。第 3 群は第 1 群と同様塩酸テ トラサイクリン注射を行ない, 離乳後20ppm のフッ素 を含む $\mathrm{NaF}$ 溶液を飲用させた群とした。第 4 群は第 1 群と同様塩酸テトラサイクリン注射を行ない, 離乳後 3 回 APF 溶液の局所塗布を行なった群とした。

子定飼育期間飼育した後, 動物を殺し, 各群の動物か ら下影第 1 臼歯を抜去して，エナメル犋の耐酸性と微小

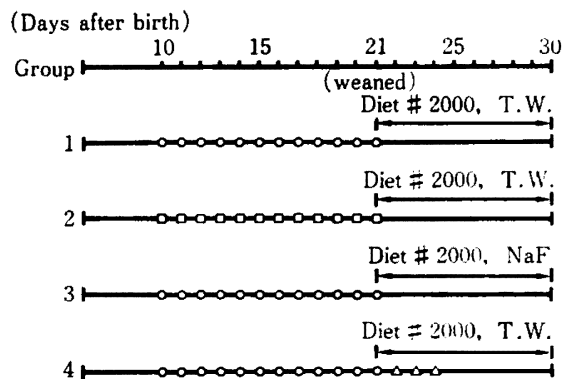

Note. T.W. : Tap water NaF : NaF solution 0 : Injection of tetracycline hydrochloride : Injection of saline solution

$\Delta$ : Topical application of APF solution

Fig. 8 Experimental schedule (experimental 3).

硬度の測定のための試料とした。

1）エナメル梊耐酸性

エナメル啠耐酸性は各群 10 試料について，0.1 M 酢 酸一酢酸ナトリウム緩街液に溶出した Ca 量で比較し た。連続 3 回の脱灰を行なった各回毎の溶出 $\mathrm{Ca}$ 量, な らびに 3 回の溶出 $\mathrm{Ca}$ 量の和の平均値を Fig. 9 に示 す。各群の溶出 $\mathrm{Ca}$ 量は連続 3 回の脱灰操作でも同様の 傾向を示し，第 1 群が最も多く，第 2 群，第 3 群，第 4 群の順に溶出 $\mathrm{Ca}$ 量が少なくなる傾向がみられる。第 1 回, 第 2 回, 第 3 回の脱灰でいずれも，各群間には $5 \%$ 以下の危険率で有意な差がみられた。

3 回の脱灰操作における溶出 $\mathrm{Ca}$ 叟の合計では，第 1 群は他の各群に比べ $1 \%$ 以下の危険率で有意に溶出 $\mathrm{Ca}$ 量が多く，第 3 群，第 4 群は第 1 群，第 2 群に比べそれ ぞれ0.1\%の危険率で有意に溶出 $\mathrm{Ca}$ 量が少なかった。 また，第 4 群は第 3 群に比べ $0.1 \%$ の危険率で有意に溶 出 $\mathrm{Ca}$ 堽が少なかった。 


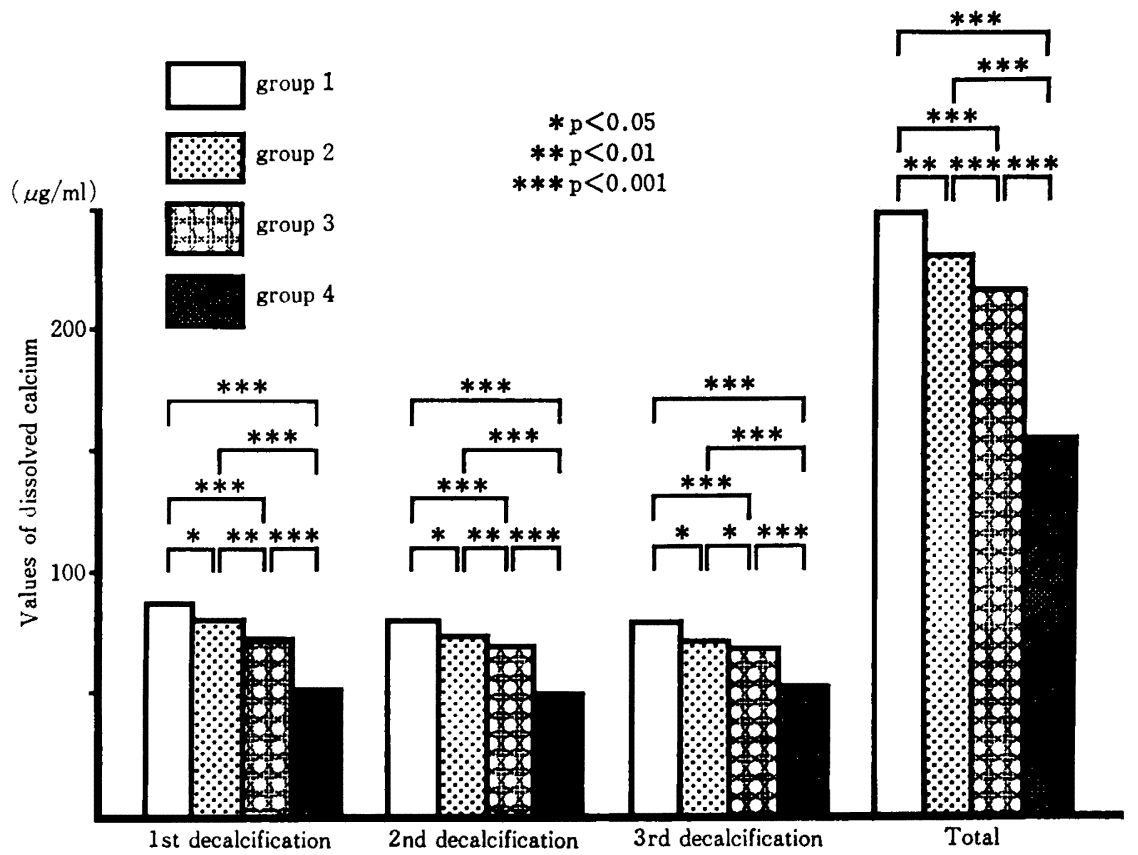

Fig. 9 Values of dissolved calcium in $0.1 \mathrm{M}$ acetic acid buffer.

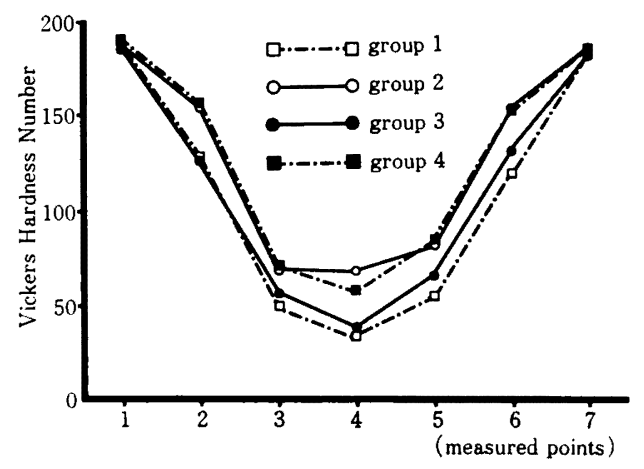

Fig. 10 Microhardness on enamel.

\section{2）エナメル所微小硬度}

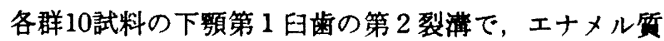
中に 7 つの測定点を設定して微小硬度の測定を行なった 平均值を Fig. 10 に示す。各群とも裂淟上部では硬度 が高く, 裂淟底部に向かうに従い硬度が低くなる傾向が みられた。

第 1 点, 第 7 点では各群間に有意な差はみられなかっ た。しかし第 2 点から第 6 点（裂溝開口部 3 分の 1 の測 定点から裂淟底部へ向かって設定した各測定点）では，

第 1 群, 第 3 群は第 2 群, 第 4 群よりもいずれの測定点 においても硬度が低い傾向がみられた。第 1 群，第 2 群 間では第 2 点から第 6 点のすべてについて $5 \%$ 以下の危
険率で有意な差がみられた。また，第 1 群と第 3 群の間 でも 4 つの測定点で $5 \%$ 以下の危険率で有意な差がみら れた。

\section{考察}

テトラサイクリン系薬物は広域性抗菌スペクトルをも つ抗生物梊で，感染性疾患の治療に投与されることが多 いが,歯の形成期にこの薬凨が投与されると苗に沈着

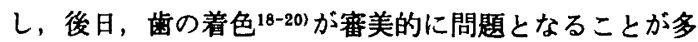
い。

テトラサイクリン系薬侴を投与された既往歴があり， 着色の見られる歯の触䍜患性についてW allman ら21)， Witkop ら 22)，Kline ら ${ }^{231}$ はテトラサイクリン系薬㓮の 投与を受けた歯では网触の発生が多かったと報告してお り, Brearley ら ${ }^{24)}$, Radtke ら ${ }^{25)}$ は逆に㽪蝕の発生は少 なかったと述へている。また，Weyman ${ }^{26)}$, Hamp ${ }^{27) ，}$ Genot ら ${ }^{28)}$, Rebich ら ${ }^{291}$ は蹒触の発生に差はなかった と報告している。このようにテトラサイクリン采薬郕に よる着色歯の歭触䍜患性については意見の一致を見てい ない。

動物を用いた実験触触に関する研究では，テトラサイ クリン系薬剤を口腔内微生物の発育を抑制する目的で用 いた研究 ${ }^{80-871}$ は多いが，臼歯の形成時期にテトラサイク リン系薬剤を投与した動物について解触の発生状況を検 
討した研究は岡田ら ${ }^{88)}$, 田中ら ${ }^{89)}$, Radtke ら ${ }^{(0)}$ の研究 の他には見当らない。

岡田ら ${ }^{38)}$ は八ムスターに塩酸テトラサイクリンを 4 日 跲より 3 日毎に 6 回腹腔内注射し，対照群との蚛罹患 状虑を調へたところ，塩酸テトラサイクリン投与群の臼 画は馆強による崩壊が対照群より著しい傾向にはある が，両群間に有意な差は認められなかったと報告してい る。田中ら ${ }^{391}$ は塩酸ミノサイクリンを 2 日龄から50日龄 まで 1 日おきに体重 $10 \mathrm{~g}$ 当り $0.15 \mathrm{mg}$ 腹腔内注射したラ ットでは，重症の触が生じたと報告している。また， 細菌学的検索を行なった結果では, 塩酸ミノサイクリン 投与群と非投与群との間に口腔内常在菌の違いが钼察さ れなかったことから，腹腔内に注射した塩酸ミノサイク リンや，画に沈着した塩酸ミノサイクリンは菌叢に影警 を与えるよりもむしろ歯質に対して蝹蝕感受性を高める 働きをしているのではないかと述べている。Radtke ら は妊娠中にロリテトラサイクリンを投与された母ラット から生まれた仔ラットに対し，22日龄から35日跉まで毎 日, 体重 $10 \mathrm{~g}$ 当り $0.25 \mathrm{mg}$ のロリテトラサイクリンを腹 腔内注射してその触の進行状況を調べ，ロリテトラサ イクリンを投与したラットでは䑤蝕の進行が遅く, これ はロリテトラサイクリンの抗菌作用によるものではない かと述べている。

動物を使った硬組織形成の研究では，時刻描記法の ためにテトラサイクリン系薬郕の投与が行なわれてい

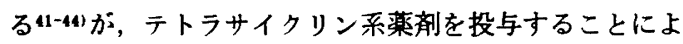
り硬組幽に石灰化不全を生じることも知られている。 Bevelander ら ${ }^{45}$ は $5 \mathrm{mg}$ の塩酸テトラサイクリンを 2 週跲より毎日連続 5 日間注射したラットの四歯には可視 光線および紫外線下にて顕微鏡で石灰化不全が短察され たと報告しており，Hammarström ${ }^{46)}$ は体重 $10 \mathrm{~g}$ 当り $0.5 \mathrm{mg}$ の塩酸テトラサイクリンを腹腔内注射したラッ トの日歯にマイクロラジオグラムで低石灰化部が珰めら れたと報告している。また，McIntosh ら ${ }^{47)}$ は種々の㢳 度と種類のテトラサイクリン系薬剤を用い, 形成不全の 発生状況を可視光線および柴外線下にて影微鏡で調べ, 体重 $10 \mathrm{~g}$ 当り $0.5 \mathrm{mg}$ が臼崡エナメル質に形成不全を起 こす最低濃度であったと報告している。

本研究ではテトラサイクリン系楽剈として塩酸テトラ サイクリンを体重 $10 \mathrm{~g}$ 当り0.5mg, 10日龄から毎日 1 日 1 回投与したが, 前述の報告から考えて, 今回使用した 浱度と投与量でラットの臼歯のエナメル質には石灰化不 全が生じているものと推測される。また塩酸テトラサイ クリンの投与方法は, 大野の報告48)を参考にして, 塩酸
テトラサイクリンが比較的持続的に吸収されて, 齒質に 磁漫性に作用するように皮下注射した。投与時期は，ラ ットの齿の形成時期 49,50) 考虑し, 第 1 , 第 2 臼齿エナ メル質の形成期から石灰化期に相当する10日龄から離乳 時までとした。

本研究において塩酸テトラサイクリン投与群では10日 龄から雄乳時までの投与期間中は体重の增加量が少なか った。McIntosh ら (7), 平居51) もテトラサイクリン系薬 剤を投与したラットでは体重の增加が覀いと報告してお り，本実験の結果も塩酸テトラサイクリン投与の影攻に よるものと思われた。しかし，投与終了後は体重は順調 に增加し，投与期間中の体重の増加不足を補い, 飼育終 了時には対照群と同程度の体重であった。

1. 培酸テトラサイクリンを投与したラットの触蝳羅 㭧状態について

実験 1 では飼育期間の長短による塩酸テトラサイクリ ン投与群の部強発生状態を対照群と比較して検討した。 10日龄より離乳時まで塩酸テトラサイクリンを投与した 実験群とその対照群はともに飼育期間が長くなるに従い

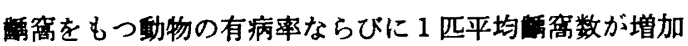
したが，いずれの飼育期間の場合も実験群の方が対照群 に比へ高い数值を示した。しかし, 初期既蝕裂清の発生 状態を検索した結果では, 実験群は対照群に比べ1匹平

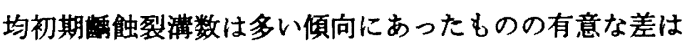

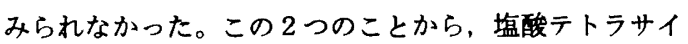
クリンを投与した群では初期船強の発生は対照群と同程

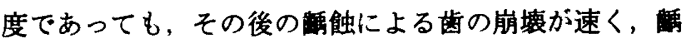
禽の形成が早い時期から起こるものと考えられ、これは 岡田ら ${ }^{38)}$ ，田中ら ${ }^{39)}$ の報告とも類似している。

武井 ${ }^{18)}$ はラットの臼歯を早期に出眼させた場合には, エナメル質に石灰化の未熟なところがあり，餜蝕による 歯質の崩壊が著しいことを報告している。本研究におい て実験群で简登生が多かったのも、テトラサイクリ ンの投与によりエナメル蜇に石灰化不全が生じていたた めと推測された。すなわち, 齔の形成, 石灰化の時期に 石灰化不全を起こした歯では，一度触触に䍜患すると歯 蜇が崩壊し易く，その後の進行が速くなるものと考えら れる。

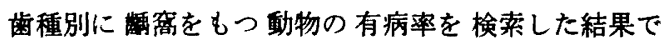
は，対照群で鸼莬をもつ動物の有病率がどの齿において も飼育期間が 長くなるほど高い数值を 示寸傾向がみら れ，下矤第 2 臼歯（以下 $\bar{M}_{2}$ と記す）が最も早く高くな り，ついで下顥第 1 臼歯（以下 $\bar{M}_{1}$ と記す），上頻第 2 臼 歯 (以下 $\underline{M}_{2}$ と記す), 上䫑第 1 臼歯（以下 $\underline{M}_{1}$ と記す） 
の順で高い数值になる。このことから，本実験に使用し たラットの触抵抗性は $\overline{\mathbf{M}}_{2}$ が最も低く, 次いで $\overline{\mathrm{M}}_{1}$, $\mathrm{M}_{2}, \mathrm{M}_{1}$ の順に高いと考えられた。実験群の動物の場合 も同様の傾向がみられるが，いずれの歯でも対照群のそ れより高い数值を示し，触抵抗性は減弱していると考 えられた。

実験群と対照群を比較すると $\overline{\mathrm{M}}_{2}$ は60日蝡で有意な差 がみられ， $\overline{\mathrm{M}}_{1}$ は70日龄，筑 は80日㱓でそれぞれ有意な 差がみられた。これは， $\overline{\mathrm{M}}_{2}$ では実験群は60日龄で対照 群との間に差異が珰められるほどに毞窝のある勤物が增 加するが，その後の増加は少ない。一方，対照群では実 験群より遅く70日秢，80日龄になって龇窝をもつ動物が 多くなるために両群間の差異が認められなくなったもの と思われる。

$\overline{\mathrm{M}}_{1}$ は $\overline{\mathrm{M}}_{2}$ に比べると本来の触抵抗性が少し高いた めに，60日龄では両群の差の有意性は認められないが, 70日龄で差が明らかになり，80日龄では対照群も謧を もつ動物が多くなり，差異がみられなくなったと考えら れる。 $\mathrm{M}_{2}$ ではさらに触抵抗性が高いため，80日龄で ようやく有意な差が琶められたものと思われる。 $\mathrm{M}_{1}$ で は80日辇令でも差異は認められなかったが，さらに飼育期 間が長くなれば， $\mathrm{M}_{1}$ にも差異が認められるのではない かと推測される。これらの結果を総合して考えると, 実 験群の動物ではどの歯も䟧触抵抗性が対照群の動物の齿 に比べて低くなっているものと考えられた。

2. 聕酸テトラサイクリンを投与したラットの迷の涌 酸性と徵小硬度について

Pilz ら ${ }^{52)}$ はオキシテトラサイクリンおよびロリテト ラサイクリンを腹腔内注射したウサギのエナメル啠の耐 酸性は対照群に比へ低かったと報告している。本実験で も塩酸テトラサイクリンを投与した群の $\overline{\mathrm{M}}_{1}$ では対照群 のそれに比へ有意にエナメル質の溶出 $\mathrm{Ca}$ 量が多く, 耐 酸性は低い結果が得られ，これが鹤触抵抗性を低くする ひとつの要因となっているものと考えられた。

本実験における微小硬度の測定結果では塩酸テトラサ イクリンの投与如何にかかわらす, 両群とも裂渾開口部 付近で硬度が最も高く, 裂溝底部に向からに従い硬度は 低くなる傾向がみられた。エナメル質の微小硬度は無機 質含有量が多いほど高くなる58-55) といわれていることか ら，本実験に使用した陚料では裂湴底部に向かうほど石 灰化度は低かったものと思われる。これは裂满開口部付 近に比へ裂瑇底部の石灰化時期が遅く50), 微小硬度の测 定に用いた試料が30日龄の $\overline{\mathbf{M}}_{1}$ であるので，萌出後のエ ナメル質の成熟がまだ十分でないためと考えられた。
須贺 ${ }^{36)}$ によるとエナメル梊の石灰化は基質形成期と石 灰化期（成熟期）の 2 期に大別できるという。テトラサ イクリンによる石灰化不全は, 有機性基倎の形成障害に より 2 次的に生じる ${ }^{44,46,57)}$ という説と, テトラサイクリ ンがカルシウムと複合体を形成し結晶核の形成や結晶成 艮を阻害することにより生じる58,58) という説がある。本 実験においてテトラサイクリンの投与を始めた10日龄で は， $\overline{\mathbf{M}}_{1}$ の裂清開口部付近はすでに基啠形成期から石灰 化期への移行期であると考えられ，テトラサイクリンに よる障害が少なかったこと，さらに裂清開口部付近は萌 出後唾液などにより 2 次的石灰化が起こり易い埸所であ ることが重なり，塩酸テトラサイクリンを投与しなかっ た群と同程度の微小硬度を示したものと思われる。しか し，裂㹸中央部から底部にかけては塩酸テトラサイクリ ン投与の影翬が影著に現れて, 微小硬度に差がみられた ものと考えられた。

Baker $^{60)}$ は，テトラサイクリン系薬阂の投与を受けた 歯の微小硬度と比重を測定し，エナメル啠のテトラサイ クリン系薬剤による着色部は健全部に比べ有意に硬度が 低く，比重も低かったと報告している。Pilzら611もオキ シテトラサイクリンおよびロリテトラサイクリンを腹腔 内注射したウサギのエナメル犋の微小硬度は対照群のそ れに比へ低かったと述べている。これら先人の報告から 考え，齿の形成，石灰化時期にテトラサイクリン系楽剤 を投与した動物の歯は, エナメル澌の耐酸性, 微小硬度 が低く，酸に侵され易く，機珹的強度も弱い歯であるた めに，䖝触に䍜患した場合，歯罂が崩壊し易いものと思 われる。これらの結果が前述の早期に䃌窝をもつ動物が 多く出現することと関連があると考えられた。

\section{3. フッ化物投与の影督について}

実験 2 では，歯の形成，石灰化期に塩酸テトラサイク リンを投与した動物についてフッ化物を応用し，その予 防効果を険討した。フッ化物の作用機序にはエナメル犋 の耐酸性の向上, 口腔内細菌に対する静菌, 抗酵素作用, エナメル梊結晶構造の安定化，再石灰化の促進などの作 用があるとされているが，本実験ではフッ素を作用さ せ，主に歯質を增強することによってエナメル犋の崩 壊、形窝の成の抑制が可能か否かを検討した。

龇蝕予防のためのフッ化物応用の手段には微量のフッ 素を長期にわたって飲用させる方法と，比較的高㗳度の フッ素を局所的に応用する方法があるが，本実験ではそ の両者を別々の群として実験を行なった。

本実験において $\mathrm{NaF}$ 溶液の 飲用を開始した時期は $\mathrm{M}_{1}, \mathrm{M}_{2}$ の萌出後であるので, $\mathrm{NaF}$ 溶液を埴用させた群 
では萌出後に直接フッ素が歯に作用したことになる。こ

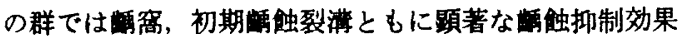
がみられたが，特に初期裂瑇龋触に対しては，APF 溶 液を局所叙布した場合よりも5\%の危険率で有意に高い 鸹触抑制効果がみられた。

飲用に用いた $\mathrm{NaF}$ 溶液は Auskaps ら ${ }^{\text {(2) }}$, Firestone

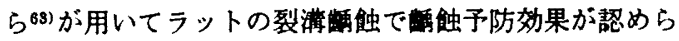
れたという20ppm のF笠度溶液を用いたが，最近，Spuller $5^{55)}$, Beiraghi $ら^{641}$ は0.25 $1 \mathrm{ppm}$ のフッ素洤度 でもラットの触を予防できると報告している。本実験 で動物が拯取する $\mathrm{NaF}$ 溶液は $20 \mathrm{ppm}$ としても裂满底 部に到達するフッ素渡度はさらに低くなる可能性はある が，石灰化不全の画に対して低濐度でも長期間綵り返し

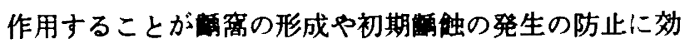
果のあることが示唆された。

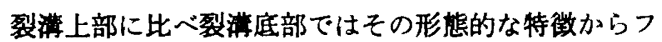
ッ素の取り込みは少なく，捓触抑制効果も低いと報告さ れている ${ }^{85,68)}$ 。しかし，今回の実酫ではフッ化物を応用

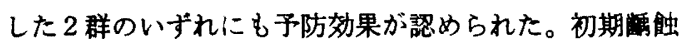
の発生において, $\mathrm{NaF}$ 溶液㰣用群の予防効果が大きか ったのは, APF 溶液を局所塗布した群が離乳直後の 3 回のフッ素に対する暴露であったのに対して, $\mathrm{NaF}$ 溶 液を飲用させた群の場合は離乳後の飼育期間中毎日 $\mathrm{NaF}$ 溶液に綝り返し暴露されるので，比較的到達しに くい裂淟底部にもフッ素溶液の到達する機会が多かった ためではないかと考えられた。

菊種別にみると,フッ化物応用群では $\mathrm{M}_{2}, \overrightarrow{\mathrm{M}}_{1}$ で有意

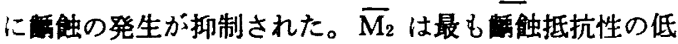

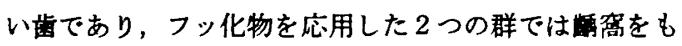
つ動物の有病事は幾分堿少したものの，今回の実験では 有意に重䆚の形成を抑制するには至らなかった。これは, この画の蝕抵抗性が本来低いことに加え, 塩酸テトラ サイクリンを投与してさらに触触抵抗性が低くなったた めに, 今回のフッ化物の応用手段では十分な予防効果を 発揮するまでには至らなかったものと考えられる。

$\overline{\mathbf{M}}_{1}$ は $\overline{\mathrm{M}}_{2}$ に比べるとれほど蛽抵抗性が低くない

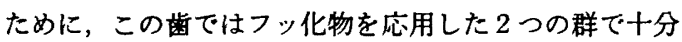
部窝の形成を防止する勃果が認められた。 $\underline{\mathrm{M}}_{2}$ は $\overline{\mathrm{M}}_{1}$ に 比へると形窝の形成防止の効果は低かったが，フッ化物

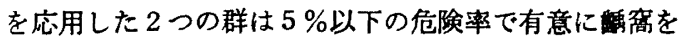
もつ動物の有病率を低く抑えることできた。また， $\mathrm{M}_{1}$ はこの 4 本の日歯の中では姃強抵抗性が最も高い歯であ

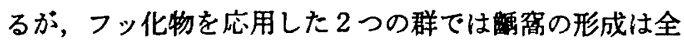
くみられなかった。すなわち，有意性については計算で
きなかったが，対照としてフッ菜を応用しなかった群に 比へてて蠤触の発生を予防していると考えられた。

フッ化物を応用した $2 つ の$ 群の 耐酸性の 測定結果で は，フッ化物を応用した群の溶出 $\mathrm{Ca}$ 量は少なく、フッ 化物の応用により耐酸性が付与されることが示唆され た。APF 溶液を局所塗布した群の方が $\mathrm{NaF}$ 溶液を飲 用させた群よりも溶出 $\mathrm{Ca}$ 量が少なかったが，これは， この実験に供した試料が 30 日齢の動物のものであり， $\mathrm{NaF}$ 溶液飲用群ではまだ十分フッ素が歯に取り込まれ ていないためではないかと考えられる。

微小硬度の測定では， $\mathrm{NaF}$ 溶液を飲用させた群では 硬度の回復はみられなかったが，APF 溶液を局所塗布 した群では歯の形成，石灰化時期に生理食塩水を投与し た群とほほ同程度にまで硬度が回復した。 $\mathrm{NaF}$ 溶液飲 用群のエナメル犋の微小硬度が低かったのも耐酸性試駼 の結果と同様，フッ素がまだ歯に十分取り还まれていな いためと考えられた。

フッ素によりエナメル兵の初期競触の再石灰化が促進 され，硬度が回復することは多くの研究 ${ }^{87-70)}$ で確認され ており，Koulourides ${ }^{88)}$ はフッ素は再石灰化の速度を 4 倍に増加させ，軟化したエナメル倎の硬度をほ上んど完 全にもとの状態にまで回復させたと報告している。実験 2 においてフッ化物を応用した 2 つの群の場合は，石灰 化不全のある歯の不完全な結晶構造の保全や安定化など の作用とともに，再石灰化の促進といらフッ素の作用が 加わって, 形成が抑制されたものと考えられた。

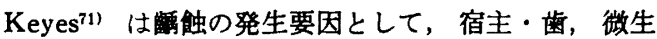
物，基澌（食物）の 3 つの大きな要因を挙げ, これら 3 要因が互いに悪い条件で部分的に重なり合う場合に醉蝕 が発生すると述へている。触の発生はこれら因子の総 合作用によるものとされているが，主要因子の 1 つが特 に顕著な場合は他の因子が微弱でも触となり得る可能 性がある。本実験の結果から考えると，齿の形成，石灰 化時期に塩酸テトラサイクリンの投与を受けた歯にお いて石灰化不全が生している場合には，宿主・歯の要因 であるエナメル啠の耐酸性や硬度が低下し，たとえ崡に 残った塩酸テトラサイクリンに抗菌作用があるとしても

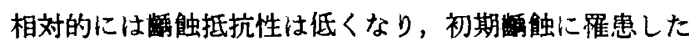
場合歯近が崩壊し易い状態にあると考えられる。またそ のような歯については萌出直後のフッ化物の応用が勃果 を示すことが示唆された。

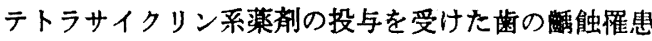
性には多くの要因が関与しており，末だ不明な点も多 い。今後, 組織学的, 細菌学的, 更に結晶構造学的検索 
を含めた多方面からの検討が必要であると思われる。

\section{結暗}

ラット告用い，歯の形成，石灰化時期に塩酸テトラサ イクリンの投与を受けた歯の触䍜患性を検哣した結 果, 塩酸テトラサイクリンの投与を受けたラットの歯で は触の進行が速く, 龇窝の形成が早い時期から起こ り，稣触抵抗性が低下していると考えられた。またこ のような歯にフッ化物を応用することで解触の発生が㧕 制されることから，このような歯に対するフッ婪の応用 は有効な政蝕予防手段であることが示唆された。

\section{影 辞}

稿を終えるにあたり，終始的切なご指道とご校閲を賜 りました，岡田昭五郎教授，尾崎文子睡師に謹んで感溇 の意を捧げます。また，本研究の実弱に際して，ご指 慗，ご協力をいただきました本学第1齿科理工学教室,

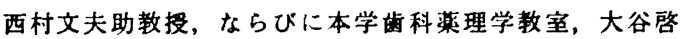
一助教授，俣木志朗噒師に，厚くお礼を申し上げます。 さらに，本研究に際し，ご援助，こ協力いたたきました 予防歯科学教室の諸先生方に心からお礼を申し上げま す。

\section{文献}

1) Mellanby, M.: Diet and the teeth. An experimental study, Part III. The effect of diet on dental structure and disease in man, Med. Res. Council. Special Reports, Series No. 191, 1934.

2) Staz, J.: Hypoplastic teeth and dental caries, South African Med. J., 17 ; 1, 1943.

3) Staz, J.: Hypoplastic teeth and dental caries, J. Dent. Res., 23 ; 220, 1944.

4) McKay, F. S. : The establishment of a definite relation between mottled enamel and the liability to decay, Dent. Cos., 71;747, 1929.

5) Dean, H. T.: Endemic fluorosis and its relation to dental caries, Pub. Health Rep., $53 ; 1685,1938$.

6) Wilson, D. C. and Surie, E. : Osteomalacia (late rickets) studies, Part IV. A prelimi. nary note on the incidence of rickets and dental caries among school children in india, Indian J. Med. Res., 17 ; 903, 1930.

7) Shelling, D. H. and Anderson, G. M. : Relation of rickets and vitamin $\mathrm{D}$ to the incidence of dental caries, enamel hypoplasia and malocclusion in children, J. Amer. Dent. Res., 23 ; 840, 1936.
8) Harcourt, J. K., Johnson, N. W. and Storey, E. : In viz'o incorporation of tetracycline in the teeth of man, Arch. Oral Biol., 7 ; 431437, 1962.

9) Bennet, I. C. and Law, D. B.: Incorporation of tetracycline in developing dog enamel and dentin, J. Dent. Res., 44 ; 788-792, 1965.

10）细原悦郎：ヒトの齿のテトラサイクリンによる ラベリング像，齿学，5；900-931，1974.

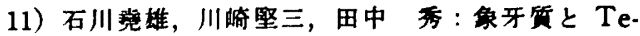
tracycline について，崡基碳誌，17；219-235， 1975.

12) König, K. G., Marthaler, T. M. und Mühlemann, H. R. : Methodik der kurzfristig erzeugten Rattenkaries, Dtsch. Zahn- Mund- u. Kieferheilk., 29 ; 99-127, 1958.

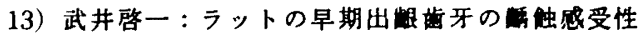
に関する研究，口街誌，32；524-540，1983.

14) Armitage, P. and Berry, G.: Statistical methods in medical research. Second edition, Blackwell Scientific Publications, London, 1971, p. 129-132.

15）小椋秀忘，加藤有三，山田庄司：多用途微量金 属分析装置に上る生物試料中の金属定量 I， 口 病誌, $44 ; 257-266,1977$.

16）小椋秀亮，山田生司，加藤有三：多用途钽量金 属分析装置による生物試料中の金属定量 II，口 病誌, $44 ; 483-491 ， 1977$.

17）山田庄司, 加藤有三, 小椋秀亮：多用途德量金 属分析装琪に上る生物試料中の金属定量而、口 病范, $47 ; 391-396,1980$.

18) Weyman, J. and Porteous, J. R. : Discoloration of teeth possibly due to administration of tetracyclines, Brit. Dent. J., 113 ; 51-54, 1962.

19) Davis, P. A., Little, K. and Aherne, W. : Tetracycline and yellow teeth, Lancet, 1962 I ; 743, 1962.

20) Wallman, I. S. and Hilton, H. B. : Teeth pigmented by tetracycline, Lancet, 1962 II ; 827-829, 1962.

21) Wallman, I. S. and Hilton, H. B. : Prematurity, tetracycline, and oxytetracycline in tooth development, Lancet, 1962 II ; 720-721, 1962.

22) Witkop, C. J. and Wolf, R. O.: Hypoplasia and intrinsic staining of enamel following tetracycline therapy, J. Amer, Med. Assoc., 13 ; 1008-1011, 1963.

23) Kline, A. H., Blattner, R. J. and Lunin, M. : Transplacental effect of tetracyclines on teeth, J. Amer. Med. Ass., 188 ; 178-180, 1964.

24) Brearley, L. J. and Porteous, J. R. : Cha- 
racteristics and caries experience of tetracycline-affected dentitions, J. Dent. Res., 52 ; 508-516, 1973.

25) Radtke, G., Erler, K. und Pörschmann, M. : Tierexperimentelle und klinische Untersuchungen zur Kariesaktivität und-progression in tetrazyklinhaltigen $Z$ ahnhartgeweben. Teil 2 : Klinische Studien, Zahn- Mund- u. Kieferheilkd., $72 ; 420-424,1984$.

26) Weyman, J. : Caries incidence in teeth with tetracycline incorporation, J. Dent. Res., 45 ; 1817, 1966.

27) Hamp, S. E.: The tetracyclines and their effect on teeth, Odont. Foren Tidsk., 75 ; 33-49, 1967.

28) Genot, M. T., Golan, H. P., Porter, P. J. and Kass, E. H. : Effect of administration of tetracycline in pregnancy on the primary dentition of the offspring, J. Oral Med., 25 ; 75-79, 1970.

29) Rebich, T., Kumar, J. and Brustman, B. : Dental caries and tetracycline-stained dentition in an american indian population, $J$. Dent. Res., 64 ; 462-464, 1985.

30) Zander, H. A., Lisanti, V. F. and Shiere, F. $R$. : The validity of hamster studies in caries control, J. Dent. Res., 30 ; 139-144, 1951.

31) Stephan, R. M., Fitzgerald, R. J., McClure, F. J., Harris, M. R. and Jordan, H. : The comparative effects of penicilin, bacitracin, chloromycetin, aureomycin, and streptomycin on experimental dental caries and on certain oral bacteria in the rat, J. Dent. Res., 31 ; 421-427, 1952.

32) Shaw, J. H. and Sweeney, E. A. : Comparative studies on the influence of antibiotic substances in dental caries in the white rat and the cotton rat, J. Dent. Res., 36 ; 349-360, 1957.

33) Zipkin, I., Larson, R. H. and Rall, D. P. : Reduced caries in offspring of rats receiving tetracycline during various prenatal and postpartum periods, Proc. Soc. Exp. Biol. Med., 104 ; 158-160, 1960.

34) Larson, R.H. and Zipkin, I. : Effect of tetracycline on the transmission of dental caries in rats, J. Dent. Res., 40 ; 264-267, 1961.

35) Larson, R. H., Zipkin, I. and Fitzgerald, R. J.: Effect of dehydroacetic acid and tetracycline on caries activity and its transmission in the rat, J. Dent. Res., 42 ; 95-102, 1963.

36) Harndt, R. : Incidence of caries in the teeth of syrian hamsters observed after administration of tetracycline during tooth development, Caries Res., 4 ; 316-317, 1975.

37) Harndt, R. : Tetracyclin und Karies, Dtsh. Zahnärztl. Zeitsch., $30 ; 741-744,1975$.

38）岡田昭五郎，塚田政司，葰内純史，木村 俊，

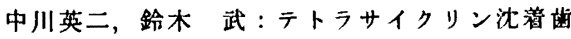
の触り患性について, 口衛誌，26；156, 1976.

39）田中倫，前田伸子：テトラサイクリン系抗生

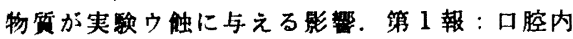
常在菌とウ螌部菌淡の比較，口街誌，32； $265,1982$.

40) Radtke, G., Erler, K. und Pörschmann, M. : Tierexperimentelle und klinische Untersuchungen zur Kariesaktivität und -progression in tetrazyklinhaltigen $Z$ ahnhartgeweben. Teil 1: Tierexperimentelle Studien, ZahnMund- u. Kieferheilkd., 72; 11-16, 1984.

41) Frost, H. M. and Villaneuva, A. R. : Tetracycline staining of newly forming bone and mineralizing cartilage in vivo, Stain Technol., 35 ; 135-138, 1960.

42) Harris, W., Jackson, R. H. and Jowsey, J. : The in vivo distribution of tetracyclines in canine bone, J. Bone and Joint Surg., 44A ; 1308-1320, 1962.

43）須賀昭一，武藏賁司：いくつかの方法によるエ ナメル啠石灰化像の比較研究，画学，51；187， 1963.

44）前田光奕：Tetracycline 投与による歯牙硬組 織のラベリングと形成異常に閣する実験的研 究, 莯学, 57 ; 40-67, 1969.

45) Bevelander, G., Rolle, G. K. and Cohlan, S. Q. : The effect of the administration of tetracycline on the development of teeth, J. Dent. Res., 40 ; 1020-1024, 1961.

46) Hammarström, L.: Tetracycline in developing rat enamel in relation to protein synthesis and maturation, Acta Odont. Scand., 26 ; 337-356, 1968.

47) McIntosh, H. A. and Storey, E. : Tetracycline-induced tooth changes, Part 4. Discoloration and hypoplasia induced by tetracycline analogues, Med. J. Aust., 1 ; 114-119, 1970.

48）大野康亮：テトラサイクリンによる形成期硬組 織のラベリング像に及ぼす諸条件につい下，歯 基硽誌, $20 ; 252-269,1978$.

49) Cheyne, V. D. : Production of graded mottling in molar teeth of rats by feeding of potassium fluoride, J. Dent. Res., 21 ; 145$155,1942$.

50) Kurahashi, Y., Nagai, N., W atanabe, K., Watanabe, H. and Yama, K. : Chronologi- 
cal observation of the odontogenesis of rat molars, Bull. Tokyo Dent. Coll., 9 ; 147159, 1968.

51）平居夕美子: Oxytetracycline の齿啠取り込み と硬組樴一の影整, 藏科医学, $40 ; 84-100$, 1977.

52) Pilz, W. und Radtke, G.: Über die Säurelöslichkeit der Zahnhartgewebe des Kaninchens nach interner Applikation verschiedener Antibiotika, Zahn- Mund- u. Kieferheilkd., 67 ; 265-272, 1979.

53) Davidson, C. L., Hoekstra, I. J. and Arends, J. : Microhardness of sound, decalcified and etched tooth enamel related to calcium content, Caries Res., 8 ; 135-144, 1974.

54) Featherstone, J. D. B., ten Cate, J. M., Shariati, M. and Arends, J.: Comparison of artificial caries-like lesions by quantitative microradiography and microhardness profiles, Caries Res., 17 ; 385-391, 1983.

55) Spuller, R. L., Beiraghi, S., Rosen, S. and Beck, F. M. : The effect of low levels of sodium fluoride in drinking water on the incidence of dental caries in rats, Caries Res., 20 ; 556-558, 1986.

56）須賀昭一：水久齿萌出期の齿科，歯界展望別冊， 医齿薬出版，東京，1984，25-40頁.

57）小椋秀亮：薬物投与による硬組織の形成障害, 口病誌, $37 ; 69-77,1970$.

58) Kaitila, I. : Effect of tetracycline on mineralization in cycloheximide-treated bones in vitro, Calc. Tiss. Res., 7 ; 46-57, 1971.

59) Caswell, A. H. and Hutchinson, J. D. : Selectivity of cation chelation to tetracyclines. Evidence for special conformation of calcium chelate, Biochem. Biophys. Res. Comm., 43 ; 625-630, 1971.

60) Baker, K. L.: The fluorescent, microradiographic, microhardness and specific gravity properties of tetracycline-affected human enamel and dentine, Arch. Oral Biol., 17 ; 525536, 1972.

61) Pilz, W. und Radtke, G. : Veränderungen der Mikrohärte der Zahnhartgewebe des Kaninchens nach internen Antibiotikagaben, Zahn-Mund-u. Kieferheilkd., 67 ; 689-695, 1979.

62) Auskaps, A. M. and Shaw, J. H. : Hemoglobin concentration, thyroid weight and growth rate in rats during minimum fluoride ingestion, J. Nut., $55 ; 611,1955$.

63) Firestone, A. R. and Navia, J. M. : Sulcal plaque $\mathrm{pH}$ and remineralization of sulcal caries in rats exposed to dietary and water fluoride, Caries Res., 22 ; 177-180, 1988.

64) Beiraghi, S., Spuller, R., Rosen, S., Wilson, S. and Beck, F.: Effect of low-level fluoride and caries incidence in rats, Caries Res., 23 ; 168-171, 1989.

65）可児瑞夫，可児德子，饭野新太郎，広瀬晃子， 磯䗁第則, 伊川英二, 奥野雅典, 加藤裕久 : ᄀ ッ化チタンフンモニウムによるラット実䀦う䖵 抑制勃果, 口街誌, 37 ; 63-71，1987.

66) Wetherell, J. A., Robinson, C. and Best, J. S. : Influence of anatomical site on fluoride levels in rat molars, Caries Res., 15 ; 386$392,1981$.

67) Head, J.: A study of saliva and its actions on tooth enamel in reference to its hardening and softening, J. Amer. Med. Assoc., 59 ; 2118-2122, 1912.

68) Koulourides, T. : Art and science of dental caries research, Academic Press, New York, 1968, p. 335-378.

69) White, D. J. and Featherstone, J. D. B. : A longitudinal microhardness analysis of fluoride dentifrice effects on lesion progression in vitro, Caries Res., 21 ; 502-512, 1987.

70) Reintsema, H. and Arends, J.: An in vivo study of microhardness and fluoride uptake in partially demineralized human enamel covered by plaque, J. Dent. Res., 67 ; 471-473, 1988.

71) Keyes, P. H.: Present and future measures for dental caries control, J, Amer. Dent. Assoc., 79 ; 1395-1402, 1969. 